\title{
Physical - chemical geotechnology. Instrument for the superior valuation of mineral resources and environmental protection
}

\author{
Victor Arens ${ }^{1}$, and Iulian Offenberg ${ }^{* 2}$ \\ ${ }^{1}$ Russian Academy of Natural Sciences, Altufievskoe Shosse Of. 65, Moscow, \\ Russia \\ ${ }^{2}$ University of Petrosani, IMIT, Universității no.20, Petroșani, Romania
}

\begin{abstract}
In the paper, the authors define the purpose, tasks and content of a new working tool in the exploitation and superior valuation of useful mineral substances, based on the principles of geotechnology, respectively Physical - Chemical Geotechnology (P-CG). It presents the vision on Mining Geotechnology as a relatively new science, its theoretical outline having the role of explaining the conditions, means and methods of exploitation and processing of minerals, through underground constructions, but also some ways to adapt existing techniques. It examines how P-CG can improve working conditions, the economy, geoecology, safety production, comfort and quality of life all in the geographical environment. The authors describe the main task of P-CG as a complex structure of scientific disciplines in which all processes and transformations that occur in subsoil exploitation must be discovered, researched and solved holistically through non-standard solutions. It also outlines a roadmap for the assessment of deposits suitable for the use of P-CG methods, addresses the preconditions and what needs to be done for the widespread introduction of new technologies in the mining industry. In this sense, the structure of a business plan of a P-CG enterprise is also drawn.
\end{abstract}

\section{Introduction}

Useful mineral substances (s.m.u.) are vital elements for the development and support of modern national economies, being considered indispensable for the development of hightech technologies. In order to generate sustainable economic growth, humanity must exploit its resources in the most intelligent and sustainable possible way. It is no longer a secret, because the resources that generate economic growth, on which we have relied so far, are insufficient for the current needs of modern society and the global economy. [1]

The continuous demographic increase ( 0.2 million pers./day $)$ doubled by the consumerist middle class, determines that the demand and supply of resources to go in opposite directions. Consumption "exploded" with technological development, stimulated by global population growth, while the intensification of the urbanization process and the

\footnotetext{
*Corresponding author: $\underline{02 \mathrm{fn} b r g @ \text { yahoo.com }}$
} 
continuous increase of the standard of living have led to the reduction of the life cycle of the products. However, more products are used and more raw materials are consumed, a good example of this being the global demand for copper and iron, which is estimated to triple by 2050 . [2]

But intensive exploitation will lead to a decrease in accessible mineral resources, forcing technologies to turn to extreme conditions. As the accessible part of the earth's crust for standard technologies becomes poorer in s.m.u., the alternatives are new and advanced extraction technologies, such as micronization, dissolution, liquefaction, gasification, magma and outer space, and so on.

On the other hand, the reconsideration of environmental effects at European level over the last three decades has led to a "large-scale industrial restructuring", at national level, "reducing production and starting operational closure of the vast majority of mines"; led to job losses and serious damage on the quality of human life in communities formed as mining areas. [3] The social impact will be huge, as industrial sectors using critical useful minerals, for example, generated at EU level over $€ 1.3$ billion / year in added value and 30 million jobs in 2018-2019. [4]

In this context, new technologies must be sought to find non-standard solutions for industrial exploitation of s.m.u., minimally invasive, from deep underground geological deposits, combining knowledge from fundamental fields with earth sciences in a new concept - Extractive Geotechnology. The interdisciplinary nature of geotechnologies makes management use information specific to the various engineering sciences that make it up, with several starting points:

- a complex of methods that are interdisciplinary related;

- tasks from different areas cooperating as a whole, and

- individual ways of working from different fields replace a single discipline. [5]

\section{Scope and objectives}

The main purpose of extractive Geotechnologies is related to the knowledge of mining activities closely correlated with the evolution of real life.

The objectives are to understand the basic problems of mining science, to evaluate possible options for the use of basic sciences in mining practice, to formulate recommendations for the best technological solutions to ensure economic efficiency and safety in and after operations.

Predictive tasks are related to the study of the behavior of different mining systems under the influence of various disruptive factors. One of the most important predictive tasks of Geotechnology is to investigate the state and prospects of development of the production of useful mineral substances (s.m.u.), of new economic and ecological ways of exploration, extraction and processing, corroborated with the release of hard workers.

The geotechnical process can be defined as the totality of concomitant or subsequent operations (ordered in time) necessary to obtain a product by synthesis, processing, preparation etc. from the earth's crust (in-situ). At the same time, the Geotechnological system is defined as a structured set of means of production, interconnected by wellestablished relationships, whose functions represent the work tasks necessary to achieve the intended purpose and extractive objectives. The function of a geotechnical system will be defined by inputs (materials, energy, information) and outputs (products). At the same time, geotechnology can be defined similarly to any technology as "a system of knowledge, procedures and equipment used to make mining products" (s.m.u.).[6] 


\section{Physical and Chemical Geotechnology (GFC)}

Physical and chemical geotechnology contribute to the formation of "bridges" between the various sciences. GFC methods have been known for a long time. In recent years there have been many publications about GFC which has become a synthetic science with its own subject, object and research methods. But, excluding many significant results in salt, uranium, gold, sulfur, geothermal, so far, no major industrial taxation has been achieved, although GFC research is developing rapidly and widely for all new methods of s.m.u. discovering and removing internal and external contradictions of processes and phenomena.

Maybe the authors were insignificant? Maybe the officials weren't paying attention? Maybe the scientific structures did not disseminate the results?

Certainly, all this is related to the difficulties of thorough understanding of all the factors that should be studied, which should be directed to be studied by physicists, chemists, microbiologists and many other specialists. The GFC science school is a phenomenon associated with the formation of a new way of thinking, a new vision of mining problems and a new approach to solving them. Pioneers of the new science, such as I.P. Kirichenko (VUGI), R. N. Pitin, I.L. Farberov (IGI), N.N. Verigin (VOGEO), D.I. Shchelkachev (MGRI), A.I. Kalabin (Promniyproject). D. Diadkin (LGI), A.S. Cherniak (Irg), A.N. Scherban (AN of Ukraine), V.V. Rzhevsky (LGI), N.V. Melnikov (IPKON RAS), D.P. Lobanov (MGRI) and many others worked actively in the GFC field. It was their work that gave impetus to the development of GFC as a great opportunity to provide new mining technologies, sustainable without the presence of man in hard underground conditions. The premises were created for the new type of production and to change the work character of a person who ceases to fulfill the function of manipulator of the machine becoming supervisor and process manager. The GFC ideology is a system of opinions that gives purpose and means of combining them, it is a concrete recipe, where and what to look for, it is a connection of specialists to pragmatism, it is morality in mining research and exploitation. [1]

The main idea of the GFC is to shorten the technological operations of s.m.u. extraction. To do this, we must remember that "time is a wealth that cannot be neglected or spent without mind." GFC is a whole, and the whole is more than the sum of its parts. Our task is to widely encourage GFC's and contribute to their development, testing and introduction into industrial production. We need to encourage researchers to look for new things, as GFC can be our barricade, the last defense against an uncertain and unknown future. Because the modern challenges facing mining engineers are archaic, they can no longer be solved sometime but today. The relevance of the topic must correspond to the time that shapes the new needs and in order to achieve them it is necessary to organize the search for progressive solutions. Analyzing the subject, Prof. M.V. Lomonosov pointed out that "more and more, people need to go deeper and deeper into the earth to increase the benefit of the state" while Prof. D.I. Mendeleev reverberate his echo, stating that "in the scientific study of objects there are two main and final purposes: prediction and benefit. To anticipate or predict what is not yet known ... means to appeal to people's ability to penetrate into themselves. [1] But the triumph of scientific predictions would be of very little value to humans if it did not lead to direct common use. " In many cases, the irrationality of decisions made without sufficient scientific support for the implementation of technology has led to nonspecific results, which can be interpreted as a failure or as an isolated success of an experiment (e.g., hydro mining). These approaches are the ones that slow down the progress of many GFCs. Mistakes are possible, have been and will be made, but we should find a way out of any situation because the future catches up with us, we must not have doubts in this regard. [7] 


\section{Earth's resources. Dissipation and non-dissipation}

Due to old and inefficient standard technologies, humanity has wasted and continues to waste important mineral resources. Quantitative development has left behind qualitative development; and until research efforts yield spectacular results, standard technologies, even modernized ones, will continue to waste and disrupt the environment. Unfortunately, states and companies have offered only cost-distorted strategies in their programmatic (forecast) policies that have delayed and even blocked technological progress in the mining field, limited by resource depletion. However, analyzing the depths of exploitation, which man has managed to reach in relation to the lithosphere, we can estimate that, at present, there is a technological crisis rather than a depletion of resources. Deep in the earth's crust (lithosphere) mineral resources are not lacking. The miner's problem is to find innovative ways and appropriate geotechnologies to evaluate them, extract them sustainably, durable and at a competitive price with minimal disturbance to the geographical environment. [8]

Today, but especially in the future, the role of complementary sciences (e.g., chemistry and physics) in mining will increase as a support for increasing the depth of exploitation, productivity, security and safety of applied and applicable technologies. The practical tasks of the research are to improve performance (increased productivity, reduce losses and costs, increase occupational safety, maintain the health of the geographical environment, etc.) while increasing access to resources. [7] With the change of mining technologies, inadmissible and extremely damaging losses will be reduced. The loss (waste) of mineral resources is caused by the destructive action of dissipating factors and is called dissipation. [9] Dissipators are the cause and Dissipation is the effect. At the opposite pole we find the concentration of production by applying concentrating factors, the effect being called nondissipation of exploited mineral resources. Dissipation occurs throughout the chain of capitalization of mineral resources, representing a complex process generated by various dissipators such as: technological limitations, characteristics of the working environment, equipment wear, environmental degradation, s.m.u. to. Dissipation is accompanied, in most cases, by both loss of s.m.u., time and energy. [9]

In this sense, a special importance is acquired by the Physical and Chemical Geotechnology (GFC) - defined as a science about the methods and means of processing the mineral resources of the subsoil by transforming them inside the deposit with nonstandard processes (chemical, thermal, physical, hydrodynamic, microbiological etc.). The basis of the GFC is the underground processes of transforming the useful substance that takes place in the deposit (as reactor), which is at the same time the means and object of exploitation. The GFC must allow the working agent to move along the entire contour of the deposit and extract s.m.u. through wells, shafts or drilled channels, in conditions of production concentration. All this allows the minerals to be extracted in the form of fluids (liquid, gaseous solutions and heterogenous mixtures) through boreholes or drilled wells, followed by the extraction of useful components from the extracted products.

Principle scheme of GFC starts from the physical and chemical geotechnology for fluidization (transport of working fluids to the abutment, injection, transformation of the useful mineral substance into a fluid state and transport of the fluid to the surface, control of production parameters), processing works of the extracted product and auxiliary works (excavation, preparation, equipment, fracturing, pressure control, sealing etc.). GFC methods are usually defined as continuous processes driven by appropriate equipment and assisted by remote control and control devices. They combine the standard advantages with the possibility of exploiting poor, deep and complex geo-mining deposits, reducing costs and shortening the construction deadlines of the objectives, as well as the increasing possibility of complete automation. [1] 


\section{Material balances and process regime of GFC}

\subsection{Material balances}

Similar to standard technologies, for Physical and chemical Geotechnologies it is necessary to know the quantities, flows of substances (materials) as well as all the physical and chemical transformations that take place. Ideally, for better control of physical and chemical processes, they should be known both quantitatively and qualitatively at any time and at any point through which they flow (flow rates, quantities, concentration, state of aggregation etc.). [ 9]

Thus, it is necessary:

- primary data, such as capacity, flow, properties of raw and auxiliary materials, properties of products and co-products etc.;

- technological scheme, with specific characteristics and possible variants etc.;

- phase equilibria and chemical equilibria formed;

- stoichiometric and kinetic data of the chemical reactions that take place.

Based on these data we can write balance equations that transpose the mathematical expression of the general law of conservation of mass and energy:

$$
\sum \mathrm{G}_{1}+\sum \mathrm{G}_{2}=\sum \mathrm{G}_{3}+\sum \mathrm{G}_{4}
$$

where:

$\sum \mathrm{G} 1$ - the sum of the entered materials (input);

$\sum \mathrm{G} 2$ - sum of existing materials;

$\sum \mathrm{G} 3$ - the sum of the output materials;

$\sum \mathrm{G} 4$ - the sum of the remaining materials.

Obs. The terms Gi are expressed in quantities or in gravimetric or volumetric flows.

The difference is called accumulation (A):

$$
\mathrm{A}=\sum \mathrm{G}_{1}-\sum \mathrm{G}_{3}=\sum \mathrm{G}_{2} \cdot \sum \mathrm{G}_{4}
$$

In continuous processes, $\mathrm{A}=0$, the balance taking the form of the ideal case:

$$
\sum \mathrm{G}_{1}=\sum \mathrm{G}_{3}
$$

In practice, due to material losses $\sum \mathrm{Gp}$ the balance equation becomes:

$$
\sum \mathrm{G}_{1}=\sum \mathrm{G}_{3}+\sum \mathrm{G}_{\mathrm{p}}
$$

As the time interval for which a balance sheet is drawn up depends on the operating regime, in the case of continuous operating processes the balance sheet can be calculated for a unit of time in the form of hour, day, month or year. For discontinuous exploitation processes the quantities of s.m.u. is calculated on a batch and then related to the ton of raw material. [9]

Obs. On a transitional basis, balance sheet equations will be differentially expressed.

When, in the GFC process, from the same raw material we seek to obtain several products with different characteristics we have a coupled production, apparently or effectively.

Apparently coupled production (ACP) is achieved when, in the same period of time, from a homogeneous input material we seek to obtain two or more products with the same chemical composition but in different quantities (e.g., dissolution of a homogeneous strand 
of s.m.u., salts in solution from different caves etc.). In this case, the material balance becomes:

$$
\mathrm{G}=\mathrm{G}_{1}+\mathrm{G}_{2}+\mathrm{G}_{3}+\mathrm{G}_{4}+\ldots \ldots
$$

Effectively coupled production (ECP) is carried out when two or more products with different chemical composition (e.g., a fractional distillation, dissolution of polymetallic ores, etc.) are obtained from the same heterogeneous input material. In this case, the balance sheet will also take into account the composition of the output materials. [8]

Thus, if we have an input material $\mathrm{G}$ with a heterogeneous composition $(\mathrm{A}, \mathrm{B}, \mathrm{C} \ldots$.$) in$ percentage quantities $(\mathrm{a} \%, \mathrm{~b} \%, \mathrm{c} \%$....) from which the product $\mathrm{G} 1$ is obtained in which predominates component $\mathrm{A}$, but there are also parts of the other components (a1\%, b1\%, $\mathrm{c} 1 \%$....) the product $\mathrm{G} 2$ in which component $\mathrm{B}$ predominates, but there are also the other components in different percentage parts $(\mathrm{a} 2 \%, \mathrm{~b} 2 \%, \mathrm{c} 2 \% \ldots$.$) and so on, then a general$ balance sheet is drawn up such as:

$$
\mathrm{G}=\mathrm{G}_{1}+\mathrm{G}_{2}+\mathrm{G}_{3}+\mathrm{G}_{4}+\ldots \ldots
$$

and partial component balances:

$$
\mathrm{G} \cdot \mathrm{a}=\mathrm{G}_{1} \cdot \mathrm{a}_{1}+\mathrm{G}_{2} \cdot \mathrm{a}_{2}+\mathrm{G}_{3} \cdot \mathrm{a}_{3}+\mathrm{G}_{4} \cdot \mathrm{a}_{4}+\ldots \ldots
$$

respectively,

$$
\mathrm{G} \cdot \mathrm{b}=\mathrm{G}_{1} \cdot \mathrm{b}_{1}+\mathrm{G}_{2} \cdot \mathrm{b}_{2}+\mathrm{G}_{3} \cdot \mathrm{b}_{3}+\mathrm{G}_{4} \cdot \mathrm{b}_{4}+\ldots \ldots
$$

In this way, a system of " $n+1$ " equations with " $n$ " unknowns will be obtained, with the help of which all the input materials (entering) and output (leaving) the GFC process will be calculated, and the evolution can also be represented in a graphical form. [10]

Obs. All input materials (primary, auxiliary, etc.) as well as all output materials (primary, secondary, etc.) will be entered in the material balance.

\subsection{Stationary regime}

In stationery regime (continuous) operation of a GFC reactor the material balance is given by the equation expressing the equality of the two fluids (supply and discharge):

$$
\mathrm{W}_{\mathrm{a}} \cdot \rho_{\mathrm{a}} \cdot \mathrm{S}_{\mathrm{a}}=\mathrm{w}_{\mathrm{e}} \cdot \rho_{\mathrm{e}} \cdot \mathrm{S}_{\mathrm{e}}
$$

where,

$\rho$ - fluid density

$\mathrm{S}$ - area of the pipe section

$\mathrm{D}$ - the inner diameter of the transport pipe

$\mathrm{c}_{\mathrm{k}}$ - concentration, as a mass fraction of the " $\mathrm{k}$ " component (dimensionless parameter)

Obs. If the mixture were perfect $c_{k e}$ and $\rho_{e}$ have the same values in all pipes. [9]

When more fluids enter and leave the process, equation (9) becomes:

$$
\sum \mathrm{w}_{\mathrm{a}} \cdot \rho_{\mathrm{a}} \cdot \mathrm{S}_{\mathrm{a}}=\sum \mathrm{w}_{\mathrm{e}} \cdot \rho_{\mathrm{e}} \cdot \mathrm{S}_{\mathrm{e}}
$$

respectively for a " $k$ " component

$$
\sum \mathrm{w}_{\mathrm{a}} \cdot \mathrm{c}_{\mathrm{ka}} \cdot \mathrm{S}_{\mathrm{a}}=\sum \mathrm{w}_{\mathrm{e}} \cdot \mathrm{c}_{\mathrm{ke}} \cdot \mathrm{S}_{\mathrm{e}}
$$




\subsection{The non-stationary regime}

In non-stationary regime, the GFC process will register variations in time of the parameters, including the variation of the accumulation, which implies the writing of the balance equation for an infinitesimal interval of time - $d t$. For a continuous process in which the supply (a) and the extraction (e) are made through several pipes simultaneously and with constant flows we obtain:

$$
\sum \mathrm{w}_{\mathrm{a}} \cdot \rho_{\mathrm{a}} \cdot \mathrm{S}_{\mathrm{a}} \cdot \mathrm{dt}+\mathrm{A}=\sum \mathrm{w}_{\mathrm{e}} \cdot \rho_{\mathrm{e}} \cdot \mathrm{S}_{\mathrm{e}} \cdot \mathrm{dt}+\left(\mathrm{A}+\frac{\partial A}{\partial t} \cdot \mathrm{dt}\right)
$$

wherein the first and third terms represent the sums of the masses of fluids supplied and extracted in a time interval dt, A represents the accumulation recorded up to time " $\mathrm{t}$ " and the last term $\left(\mathrm{A}+\frac{\partial A}{\partial t} \cdot \mathrm{dt}\right)$ represents the accumulation at time $(\mathrm{t}+\mathrm{dt})$.

For a process in which the flows are not constant, the speeds are replaced by a time function, such as, $\mathrm{w}=\mathrm{f}(\mathrm{t})$ :

$$
\mathrm{w}=\mathrm{w}_{\mathrm{i}}+\mathrm{a}_{\mathrm{i}} \cdot \mathrm{t}
$$

where, $\mathrm{w}_{\mathrm{i}}$ represents the speed at $\mathrm{t}=0$ and you have a coefficient specific to the flow variability.

The partial balance for component " $\mathrm{k}$ " will be written:

$$
\sum \mathrm{w}_{\mathrm{a}} \cdot \rho_{\mathrm{a}} \cdot \mathrm{S}_{\mathrm{a}} \cdot \mathrm{c}_{\mathrm{k}, \mathrm{a}}=\sum \mathrm{w}_{\mathrm{e}} \cdot \rho_{\mathrm{e}} \cdot \mathrm{S}_{\mathrm{e}} \cdot \mathrm{c}_{\mathrm{k}, \mathrm{e}}+\mathrm{A} \cdot \frac{\partial \mathrm{Ck}, \mathrm{e}}{\partial t}
$$

The establishment of material balances has a great significance in the GFC for the management of the processes, this highlighting the quantitative relations between the important factors that govern them.

From the analysis of the balance sheets, information is obtained regarding the circulation of materials for which the direct determinations such as weighing, measuring, etc. missing or not available. The balance sheet can tell us if and where losses occur in order to intervene. Also, if there is a large dissipation, we can conclude on issues such as insufficient preparation of the process, staff or conditions.

\section{The GFC process triad}

Now, it is necessary to enrich the science of mining with revolutionary ideas, which can once again make the work of people with huge resources from the depths of the Earth attractive; in order to be able to access these riches, however, a new approach is needed. The problem of exploring the depths of the Earth (deep earth) can be compared to that of exploring beyond the low orbit of the Earth (deep space), but for the conquest of great depths by man we need new sciences, techniques and technologies.

The knowledge gained so far about the depths of the planet is far from sufficient, not only for the need for minerals but also for the needs of tomorrow's science. GFC is called upon to create the horizon for the future by expanding the use of physical and chemical best practices. There is a real opportunity to increase s.m.u extraction and make them the basis of new mining. It is therefore necessary to enter the bowels of the Earth, where rich deposits are formed and, after understanding the formation process, to learn how to extract them. [1]

To succeed in this technological leap, Spreng [11] says we need time, information and energy, a "triad" where each of the elements can replace any of the others. (Figure 1) 


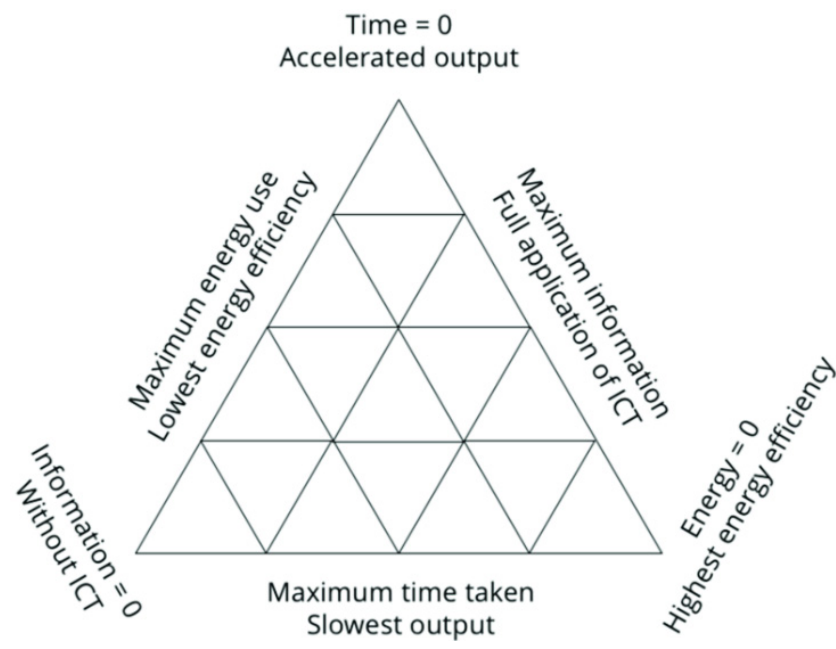

Fig. 1. Spreng's triad.

Spreng opines that energy is being replaced too slowly, introducing theoretical and practical limitations. At the same time, it finds that the efficiency has a decreasing tendency with the increase of energy (power). Therefore, he believes that energy and time can be combined; energy required for a work depending on the speed at which it must be done.[11]

Given the aforementioned consequences of dissipation and non-dissipation and their causes - dissipators and non-dissipators - GFC needs a system of knowledge, procedures and equipment used to make mining products at maximum yields and minimum specific consumptions, which tend towards theoretical values in conditions optimal exploitation and protection of the geographical environment in which it takes place. For this GFC needs to reduce the share of excessively specialized mechanization (short, simple, reliable, fluid lines, etc.), change the energy base (use of solar, wind, etc.), create a circular industry (adequacy geographic environment), the use of new materials (composites, ceramics, organics, microbiological, nanorobots, etc.), the transformation of information into a resource and the extension of the application of existing research results, the widespread introduction of artificial intelligence and IoT in extraction processes and so on. [12]

In all countries with mineral resources, the stimulation by the state of "the new" in mining, in all its aspects, is very important, because the free market does not cover the future. Therefore, is a need for regulation and support for research and development. Today's restrictive conditions make it practically impossible to test new GFC's and even more so to implement them, due to the uncertainty of the decisions of the competent authorities and the sensitivity of private investments in allocating funds for activities considered to be at technological risk. There is now a need for a change in the state's approach to mining development, in the broadest sense of the word. It is known that anyone, and even more so a decision maker, always calculates the impact of innovations on their views and finds "thousands of reasons" not to support something new, because "it is not ready for use". [1]

Based on the availability of basic sciences achievements, research analysis, experimental and applied works as well as a huge number of patented materials, the prerequisites showing what needs to be done to introduce new GFC's into the large-scale mining industry, as it is presented in Table 1. 
Table 1 - Introduction of new technologies in the mining industry.

\begin{tabular}{|c|c|c|c|}
\hline No. & Action & Problem & Expected results \\
\hline 1 & $\begin{array}{l}\text { Analysis of potential mineral } \\
\text { deposits for GFC application }\end{array}$ & $\begin{array}{l}\text { The need to develop } \\
\text { appropriate evaluation } \\
\text { criteria }\end{array}$ & $\begin{array}{l}\text { - Identification of specific } \\
\text { s.m.u. suitable for GFC } \\
\text { development }\end{array}$ \\
\hline 2 & $\begin{array}{l}\text { Creation of high-performance } \\
\text { equipment and technology for } \\
\text { opening s.m.u. deposits and } \\
\text { their exploitation with GFC, } \\
\text { drilling of drilling wells with a } \\
\text { complex profile, creation of a } \\
\text { series of types and dimensions } \\
\text { of drilling rigs }\end{array}$ & $\begin{array}{l}\text { Lack of specialized } \\
\text { processing technology } \\
\text { and extraction } \\
\text { technology for GFCs, } \\
\text { which prevents the } \\
\text { effective application }\end{array}$ & $\begin{array}{l}\text { - Reduction of drilling costs } \\
\text { 3-5 times. } \\
\text { - Increase productivity 5-7 } \\
\text { times. } \\
\text { - Creation of automatic } \\
\text { systems for tracking the } \\
\text { drilling of wells with } \\
\text { complex profile. } \\
\text { - The appearance of new ones } \\
\text { drilling rigs }\end{array}$ \\
\hline 3 & $\begin{array}{l}\text { Development of efficient } \\
\text { methods of field preparation for } \\
\text { GFC exploitation (including } \\
\text { technologies for artificially } \\
\text { improving the filtering } \\
\text { properties of the deposit site) }\end{array}$ & $\begin{array}{l}\text { Lack of new methods } \\
\text { of preparing mining } \\
\text { fields for GFC } \\
\text { exploitation; it reduces } \\
\text { the efficiency and even } \\
\text { the feasibility of } \\
\text { implementation }\end{array}$ & $\begin{array}{l}\text { - Increasing the utilization } \\
\text { rate. } \\
\text { - Reduction of reagent } \\
\text { consumption. } \\
\text { - Improving features } \\
\text { photographic fluids }\end{array}$ \\
\hline 4 & $\begin{array}{l}\text { Development of efficient } \\
\text { equipment models that meet } \\
\text { technological and economic } \\
\text { requirements }\end{array}$ & $\begin{array}{l}\text { Lack of efficient } \\
\text { construction and } \\
\text { extraction equipment }\end{array}$ & $\begin{array}{l}\text { Increased efficiency and } \\
\text { extension of GFC } \\
\text { applicability }\end{array}$ \\
\hline 5 & $\begin{array}{l}\text { Creating the theoretical } \\
\text { foundations of the physical and } \\
\text { chemical processes that take } \\
\text { place in the bowels of the Earth }\end{array}$ & $\begin{array}{l}\text { The need to develop } \\
\text { new efficient } \\
\text { procedures for passing } \\
\text { s.m.u in a fluid state }\end{array}$ & $\begin{array}{l}\text { Identifying the technical } \\
\text { feasibility of creating new } \\
\text { GFCs and optimizing } \\
\text { technologies }\end{array}$ \\
\hline 6 & $\begin{array}{l}\text { Elaboration of methods for } \\
\text { ensuring optimal regimes, } \\
\text { pumping, transport and lifting } \\
\text { of productive fluids. Creating } \\
\text { the management and control } \\
\text { system of the extraction process }\end{array}$ & $\begin{array}{l}\text { The need to manage } \\
\text { and control the } \\
\text { movement of work and } \\
\text { production fluids and } \\
\text { create their program }\end{array}$ & $\begin{array}{l}\text { Ensuring that the field is fully } \\
\text { secured with working fluids, } \\
\text { ensuring the reliability of } \\
\text { technological wells and } \\
\text { improving the production } \\
\text { process }\end{array}$ \\
\hline 7 & $\begin{array}{l}\text { Development of techniques and } \\
\text { technologies for the preparation } \\
\text { of new efficient ecological and } \\
\text { microbiological working fluids } \\
\text { for leaching }\end{array}$ & $\begin{array}{l}\text { The need for new } \\
\text { working fluids for } \\
\text { GFC, combining speed } \\
\text { and selectivity }\end{array}$ & $\begin{array}{l}\text { Reducing reagent production } \\
\text { costs, finding new reagents }\end{array}$ \\
\hline 8 & $\begin{array}{l}\text { Development of techniques and } \\
\text { technologies for the processing } \\
\text { of production fluids, including } \\
\text { gases for underground } \\
\text { gasification }\end{array}$ & $\begin{array}{l}\text { Development of } \\
\text { equipment and } \\
\text { technology for the } \\
\text { processing of } \\
\text { production fluids, } \\
\text { including underground } \\
\text { gasification gases, } \\
\text { sylvinite brines, } \\
\text { phosphorite leaching; } \\
\text { synthesis and testing of } \\
\text { high-capacity selective } \\
\text { sorbents }\end{array}$ & $\begin{array}{l}\text { - Lack of efficient technology } \\
\text { and technologies for } \\
\text { processing production fluids } \\
\text { in line with modern } \\
\text { production requirements } \\
\text { - Making new types of } \\
\text { products, reducing operating } \\
\text { costs, increasing labor } \\
\text { productivity }\end{array}$ \\
\hline 9 & $\begin{array}{l}\text { Elaboration of mathematical } \\
\text { bases and tools for modeling }\end{array}$ & $\begin{array}{l}\text { The need to optimize } \\
\text { and manage }\end{array}$ & $\begin{array}{l}\text { Reducing costs, reducing } \\
\text { development time, ensuring }\end{array}$ \\
\hline
\end{tabular}




\begin{tabular}{|c|l|l|l|}
\hline $\begin{array}{l}\text { the computational experiment; } \\
\text { solving research and production } \\
\text { problems }\end{array}$ & $\begin{array}{l}\text { technological } \\
\text { processes and their } \\
\text { control in all phases - } \\
\text { from development to } \\
\text { industrial } \\
\text { implementation }\end{array}$ & $\begin{array}{l}\text { optimal process parameters, } \\
\text { increasing the efficiency of } \\
\text { design work, improving } \\
\text { methods of control and } \\
\text { management of production } \\
\text { processes }\end{array}$ \\
\hline 10 & $\begin{array}{l}\text { Development of environmental } \\
\text { requirements for the use of } \\
\text { GFCs and measures for the } \\
\text { protection of the geographical } \\
\text { environment }\end{array}$ & $\begin{array}{l}\text { The creation of the } \\
\text { GFC determines the } \\
\text { need to regulate } \\
\text { relations with the } \\
\text { environment }\end{array}$ & $\begin{array}{l}\text { Development of specific } \\
\text { environmental protection } \\
\text { measures }\end{array}$ \\
\hline
\end{tabular}

\section{The structure of a GFC roadmap}

Each business plan follows a certain structure but is based on a similar roadmap. Without being limiting, a scheme of a roadmap for the implementation of GFC in deposits with potential in this respect, can be structured starting from the possible problems and how to solve them in a certain time interval. This is the basis for evaluating the commercial proposal, for its effective implementation and for obtaining funding. The roadmap for assessing areas promising for physical and chemical exploitation may include:

1. Summary - justification of the practical and financial feasibility of the project;

2. Justification of the project completion capacity and the company's qualifications vision, mission, values, activity description, history and legal issues;

3. Product description and competitiveness;

4. Market analysis and risk analysis - market definition and segmentation, consumer / beneficiary profile, positioning, SWOT analysis;

5. Marketing plan - sales volume and price forecast, current and in perspective promotion strategies, sales and competitiveness analysis, contracts;

6. Competitive environment - competitors, strategic partnerships, legal issues;

7. Production schedule - location, facilities, exploration / operation plan, applicable technologies and suppliers, deadlines, responsible for each activity, insurance;

8. Costs (CAPEX, OPEX etc.) and financing - budgets - potential sources of financing, profit \& loss, cash flow, analytical balances, performance indicators, debt and payment staggering, cost-benefit (CBA), threshold of profitability, discounted net value etc.;

9. Management - the system of organizational activity for the construction and management of the enterprise, the internal managerial control system, human resources policy, description of key positions, responsibilities, team profile, organization chart, recruitment and training plan, the need for external consultants;

10. Promotion, fundraising plan and expected revenues - promotional materials, presentation brochures, media articles, recommendations.

\section{Conclusion}

Mining technologies are methods of exploring mineral deposits, opening, exploiting, extracting and processing the extracted raw materials in combination with equipment and tools used in the production process for the delivery of mining products.

Geotechnology is a relatively new science, the purpose of which is not only to explain the conditions, means and methods of in-situ mineral exploitation and processing, to build underground mining structures, but especially to find the right ways to exploit them, modify and improve their economy, ecology, comfort and safety of production and facilitate simplified working conditions for the modern miners. 
GFC is today a complex science with multiple facets, in full evolution, composed of various scientific disciplines. GFC tasks are both predictive and practical, aiming to search for and confirm non-standard exploiting solutions of s.m.u. In the future exploitations of the subsoil all the processes and phenomena that appear must be individualized, researched and solved physically and chemically, this being the main task of the GFC.

\section{References}

1. В.Ж. Аренс, Геотехнология. Изд. Дом НИТУ «МИСиС», ISBN 978-5-907227-20-0 (2020)

2. I. Offenberg, N. Iliaş, S.M. Radu, I. Andraş, Tendințe ale pieței de mărfuri minerale „critice” non energetice, Proceedings 1, p. 87-91 (2017)

3. V. Jinescu, I. Avram, N. Iliaş, S.M. Radu, I. Offenberg ş.a., Pagini din istoria dezvoltării României. Construcția de echipamente, maşini și instalații pentru procese industriale - I (2018)

4. N. liaș, S.M. Radu, I. Andraş, I. Offenberg, Condiționalități ale progresului tehnico - științific în domeniul extractiv, Proc. 1, pp. 187-189, ISBN 978-9975-720-3171-1-5 (2017)

5. Offenberg I., Management de mediu si geoecologie in sectorul minier, ISBN 978-9975-3155-7-9. 504.55.06:622 0-30 (2018)

6. I. Crişan, Tehnologia ca sistem, (1980)

7. N. liaş, S.M. Radu, A. Serafinceanu, Industria minieră din România. Trecut, prezent și scenarii pentru viitor, ISBN 978-973-720-811-8 (2020)

8. I. Offenberg, N. Iliaş, S.M. Radu, Geoecologie și Geotehnologii, ISBN 978-973-720-779-1 (2019)

9. G. Preda, C. Brătianu, A.M. Socolescu, Valorificarea resurselor naturale II, ISBN 978-973-720779-1 (2005)

10. A. Angelescu, S. Vișan, A.M. Socolescu, Tehnologii industriale I (2003)

11. D.T. Spreng, On Time, Information and Energy Conservation (ORAU/IEA 78-2 R) (1978)

12. F. Bonciu, Dinamica eficienței tehnologice, (SID 100 OIDCM) (1990) 